\title{
A New Elite? Politicians and Civil Servants in Scotland after Devolution ${ }^{1}$
}

\author{
BY MICHAEL KEATING AND PAUL CAIRNEY
}

DEVOLUTION in 1999 was widely heralded as an opportunity for a 'new politics' in Scotland. Power would not only be transferred from London to Edinburgh, but would be more widely shared within Scotland. There are several dimensions to the new politics, many of which concern the revitalisation of civil society and new forms of participation. ${ }^{2}$ Our focus is more narrow, on the political and administrative elites as represented by parliamentarians and senior civil servants. As far as politicians are concerned, the aim of devolution supporters was to broaden recruitment and create a more open political class, more representative of the country as a whole. There was a specific commitment to gender equity among the parties represented in the Scottish Constitutional Convention and a vaguer commitment to representativeness on other dimensions. Devolution campaigners did not pay much attention to the civil service, in spite of a general feeling that, given the nature of the Scottish Office system, they had too much influence. There was, however, a parallel movement to broaden civil service recruitment in the UK as a whole, and to bring in outsiders, especially from the private sector, to senior positions. A decision was made at the outset to retain a single British civil service in order that officials of the Scottish Executive would have the opportunity to move back and forth from Whitehall and into European secondments, rather than being confined to opportunities in Edinburgh. Our first hypothesis, then, is that devolution has broadened the basis of elite recruitment.

In Britain and Europe more generally, however, there has been a general trend for political recruitment to narrow to the professional middle classes and those occupations that lend themselves easily to political life. ${ }^{3}$ Politics itself is increasingly a profession, with a defined career path and few possibilities for interrupting it or for entering late. Recruitment to the senior civil service may be less biased to the privately educated upper classes than in the past, but increasingly dominated by people from middle class professional families. Our counter-hypothesis is that devolution, rather than opening up politics and administration, has merely provided an opportunity to accelerate these trends, producing parallel political and administrative elites that increasingly resemble each other but are still distanced from civil society. 
In both cases, the null hypothesis is that devolution has made no difference to the prevailing trends. To test these hypotheses, we need to assess trends over time both in Scotland and in the rest of the UK. A Scottish administration had existed since 1885 in the form of the Scottish Office and had gradually extended its functions over a hundred years. Scottish MPs were somewhat distinct in their backgrounds and, while following the UK line on policy matters, had a distinct niche in the Westminster division of labour. ${ }^{4}$ So we need to identify long-term trends that may be independent of devolution and assess the extent to which Scotland was already convergent or divergent from the UK as a whole. Then to assess the impact of devolution, we need to see whether there is a break after 1999 and whether Scottish elites are diverging from their UK counterparts. In the case of civil servants, such change is liable to be slow and gradual as retirees are replaced by new recruits. In the case of politicians, we can track the evolution of the Scottish members at Westminster and compare these with the new parliamentarians elected to the Scottish Parliament.

\section{Backgrounds of MPs and MSPs}

Since the Second World War, there has been something of a convergence in the backgrounds of MPs from the two main British parties, towards the middle class, university-educated professional. Labour has lost its working-class element, while the Conservative benches have less space for the upper-class, public-school element. By no means all the old differences have disappeared, and there is a tendency among the professional classes for Labour MPs to be from the public sector and Conservatives from the private sector. Another general tendency has been the rise of professional politicians, going straight from university into political work, or at least into 'politics-enabling' professions, those that give the flexible time to devote to politics and hone the communicative skills required by politicians. ${ }^{5}$

Scotland before devolution seemed less affected by these trends. In the post-war years, parliamentary representation from the two main parties in Scotland conformed more closely than in England to the class stereotypes. ${ }^{6}$ Labour MPs were more likely to be working class, trade unionists and former councillors who entered Parliament as the culmination of a career in municipal politics. Few of them made it to high office, especially outside of their reserved domain of the Scottish Office. Scottish Conservative MPs, for their part, were disproportionately upper class, public-school educated and with military backgrounds. Indeed this tendency increased during the 1950s and 1960s with the decline of urban Toryism. ${ }^{7}$ Looking at party representatives in the early 2000s in comparison allows us in principle to assess change over time (by comparing MPs now and then) and the affects of institutional change (by comparing Scottish and non-Scottish MPs with MSPs). In practice, the comparison of Scottish MPs is limited to the Labour Party 
since the Conservatives elected no Scottish MPs in 1997 and only one in 2001 and 2005.

Comparing the backgrounds of politicians over such an extended period of time raises a number of technical difficulties. Occupational categories have changed with economic change and the growth of the tertiary sector, as government now recognises with its revised classification scheme. So working through the data with the same detailed occupational categories would not make much sense or help in resolving our central question. We are interested in changes in the broad socioeconomic pattern of representation, in particular the transformation of class politics. Yet the old class divisions are not as clear as in the past. The blue-collar workers often taken as synonymous with the working class have declined in number, but the new white-collar occupations can by no means be taken as middle-class in the older sense of the word. In any case, the standard census categories do not allow us to test our central hypothesis about the rise of professionals and the decline of the working-class representative. We have therefore designed operational categories that allow us to do this. We have grouped routine and junior white-collar workers with manual workers and distinguished these from professionals on the one hand and private business managers on the other. This gives us a fairly simple categorisation into professionals, private business managers and blue- and white-collar workers. ${ }^{8} \mathrm{We}$ have also picked out occupations that are particularly important for one or other party.

There is a large residual category, whose expansion over time is a reflection of the rise of new occupations. It also, we would argue, includes a new and important category of 'professional politicians', some of whom have worked all their careers in politics (as party workers or politicians' assistants). Others have worked in 'politics-facilitating' occupations. This is difficult to categorise. Politics-facilitating occupations as defined by Anthony King include journalists, authors and those in public relations, but also barristers, solicitors, lecturers and teachers which are in our professional category. ${ }^{9}$ The politics-facilitating occupations in our residual category include journalist, author, PR, political worker/researcher, trade union official and full-time members of a quango, interest group/think tank/lobbyist or member of another assembly—but excluding lawyers and teachers. ${ }^{10}$

The second problem is that individuals may belong in more than one category, either because they have changed occupations during their career, or because for example they may be members of professions working in a private business. To deal with this, we have used the formative occupation, that is the one in which a politician has spent most of his or her pre-parliamentary career. ${ }^{11}$ This involves some matters of judgement, especially as many Labour politicians in the post-war years were upwardly mobile. Where needed, however, we can control for this by looking at initial occupation if we want to 
know how many people are of working class origin. In fact, this distinction becomes less important over time as fewer people have started in working-class occupations.

Looking at Labour MPs (Table 1) we see that they are progressively more professional by background, but with Scottish MPs converging with their non-Scottish counterparts. The Scottish Parliament, however, marks a decisive shift, as MSPs are more 'professional' even than nonScottish Labour MPs. Looking at first occupations rather than formative ones, the institutional effect is even more marked (Table 2). Scottish MPs are still more working class in origin than other Labour MPs, but MSPs are more professional in origin than either. We also see an increase in the 'other' categories. Many of these are in the politics-facilitating occupations, including working for the parties or for MPs and MEPs. $6 \%$ of Labour MSPs had been political workers and another $6 \%$ had worked with interest groups or think tanks. By contrast, the 'other politics-facilitating' among the 1945-70 cohorts was dominated by trade union officials (about 10\% in Scotland and the rest of the UK). Since most of these would have had working-class backgrounds, the generic working class presence in that generation was even higher than our figures show. There was also in that generation a significant number who had at one time or another been insurance salesmen, presumably at that time a politics-facilitating occupation, giving flexible working hours and ample opportunity to knock on doors. Among the professions, teaching has been defined as politics facilitating by King ${ }^{13}$ and Norton ${ }^{14}$ and it is indeed heavily represented among politicians. The teaching profession has a similar weight among Labour MPs and

1. Formative occupation of Scottish Labour MPs and MSPs (\%)

\begin{tabular}{|c|c|c|c|c|c|}
\hline & $\begin{array}{l}\text { Non-Scottish } \\
\text { MPs 1945-70 }\end{array}$ & $\begin{array}{c}\text { Scottish MPs } \\
1945-70\end{array}$ & $\begin{array}{l}\text { Non-Scottish } \\
\text { MPs } 2005\end{array}$ & $\begin{array}{l}\text { Scottish } \\
\text { MPs } 2005\end{array}$ & $\begin{array}{l}\text { MSPs } \\
2003\end{array}$ \\
\hline Professional & 40.1 & 36.1 & 43.7 & 46.3 & 56.0 \\
\hline Business & 10.1 & 5.2 & 7.7 & 4.9 & 4.0 \\
\hline $\begin{array}{l}\text { Blue-collar and } \\
\text { white-collar }\end{array}$ & 23.2 & 42.3 & 8.4 & 9.8 & 2.0 \\
\hline $\begin{array}{l}\text { Other-politics } \\
\text { facilitating }^{12}\end{array}$ & 23.8 & 15.5 & 31.8 & 29.3 & 32.0 \\
\hline Other miscellaneous & 2.8 & 0.9 & 8.4 & 9.8 & 6.0 \\
\hline
\end{tabular}

2. First occupation, Labour MPs and MSPs

Non-Scottish MPs 2005 Scottish MPs 2005 MSPs 2003

Professional

Business

Blue-collar and white-collar

Other-politics facilitating

Other miscellaneous

\section{4}

10.2

10.5

25.6

9.3
41.5

7.3

22.0

22.0

7.3
54.0

4.0

10.0

24.0 
MSPs but the former include more university lecturers and the latter more school teachers (a fifth of all Labour MSPs).

There has been a trend over the years for Labour MPs to be drawn more from the professions and to converge in some respects with the Conservatives. ${ }^{15}$ These findings, consistent with other analyses, ${ }^{16}$ show that the Scottish Parliament has resulted in a marked acceleration in the shift of Labour representation away from traditional working-class backgrounds to the professional middle classes. There is still evidence of upward mobility, comparing first (not shown) with formative occupations, but the difference between Holyrood and Westminster remains.

On the Conservative side (Table 3), we have included farmers and landowners separately to illustrate the decline of this element in the rest of the UK, but the continuation of its significance in Scotland since the 1950s and 1960s. The rise of the professions is evident here (as with Labour), as is the decline in the presence of business people. The main shift in the professional category is the decline of the military officer, who between 1945 and 1970 accounted for $8 \%$ of all Conservative MPs and no less than a quarter of Scottish Conservatives. There is some evidence of people having worked all their lives in politics among the Westminster contingent but not in Scotland. It should be said, however, that the number of Conservative MSPs (18) is too small to read a lot from the percentages. The $6 \%$ of workers in the ranks of Tory MSPs is not a trend since it only amounts to one person. On the Conservative side the difference between first occupation and formative occupation is less significant, except for a group of people who moved into business in the course of their careers and one MSP who moved from shipping to a career in farming. As mentioned earlier, we cannot do a statistical analysis on the backgrounds of Scottish Conservative MPs after 1997, but a glance at the figures for 1992 (when they returned eleven members, still too few for statistical significance) suggests that the professional dominance was already established (without the military officers) but that the farmers had disappeared. Their limited return in the Scottish Parliament is therefore interesting.

The professional bias also extends to Scottish ministers, over $60 \%$ of whom are from this background. Among UK ministers, the number of professionals is lower $(40 \%)$ but there is a stronger representation than in Scotland of business, despite the fact the UK government was

3. Formative occupation of Scottish Conservative MPs and MSPs (\%)

$\begin{array}{lcccc} & \begin{array}{c}\text { Non-Scottish } \\ \text { MPs 1945-70 }\end{array} & \begin{array}{c}\text { Scottish MPs } \\ \mathbf{1 9 4 5 - 7 0}\end{array} & \begin{array}{c}\text { Non-Scottish } \\ \text { MPs 2005 }\end{array} & \begin{array}{c}\text { MSPs } \\ 2003\end{array} \\ \text { Professional } & 39.9 & 44.0 & 36.8 & 55.6 \\ \text { Business } & 41.8 & 28.0 & 43.0 & 16.7 \\ \text { Blue-collar and junior white-collar } & 0.40 & 0.3 & 1.0 & 5.6 \\ \text { Farmer/landowner } & 9.9 & 18.6 & 3.6 & 16.7 \\ \text { Other-politics facilitating } & 6.4 & 2.8 & 13.0 & 5.6 \\ \text { Other miscellaneous } & 1.6 & 6.3 & 2.6 & 0\end{array}$


homogeneously Labour while in Scotland Labour shared power with the Liberal Democrats.

Of course, these trends might just reflect changes in Scottish society as a whole. There is some truth in this, but it by no means explains the trends over time or the differences between Scotland and England and between Holyrood and Westminster. Scotland's occupational structure has resembled that of England since at least $1921^{17}$ but the convergence in the backgrounds of politicians is recent and particularly marked with the arrival of the Scottish Parliament. The proportion of MSPs from a professional background is higher than in Scottish society as a whole and the domination of political representation by the professional classes has increased faster than among the population at large. ${ }^{18}$ The almost complete absence of the lowest occupational category in the Scottish Parliament contrasts with its continuing strong presence in Scottish society. ${ }^{19}$

Educational backgrounds also show a shift over time and between institutions. Among Scottish Labour MPs the proportion with higher educational qualifications increased steadily from 1945 to 2005 but lagged consistently behind that of non-Scottish MPs (Table 4). ${ }^{20}$ By $2005,78 \%$ of Scottish Labour MPs and 91\% of non-Scottish Labour MPs had tertiary qualifications. Among Labour MSPs it was $90 \%$. Nearly all the Scottish Labour politicians took their higher education in Scotland, with only two MPs and no MSPs educated at Oxbridge, compared with a fifth of non-Scottish Labour MPs. The proportion of nonScottish Labour MPs educated privately has remained at around 20\% since the war. It was always much smaller among Scottish MPs and only two Labour MSPs in 2003 were educated privately. Again, this is not adequately explained by differences in the levels of private education in Scotland and England (currently 3.5\% and 6\%, respectively).

There was also a steady rise in graduates among Scottish Conservative MPs between 1945 and 1970 (from just over 50\% to nearly 80\%) (Table 5). The proportion of Oxbridge graduates actually increased over these years from $40 \%$ to $65 \%$, as did the proportion of private school products (from $46 \%$ to over $80 \%$ ). This was connected with the changing fortunes of Scottish Toryism, which historically had its origins in Liberal Unionism of the late nineteenth century. The Unionist element was dominant until after the Second World War, and until 1965 the party was officially called the Scottish Unionist Party, with no reference

4. Educational background of Labour MPs and MSPs (\%)

$\begin{array}{lccccc} & \begin{array}{c}\text { All Labour } \\ \text { MPs 1945-70 }\end{array} & \begin{array}{c}\text { Scottish MPs } \\ \mathbf{1 9 4 5 - 7 0}\end{array} & \begin{array}{c}\text { Non-Scottish } \\ \text { MPs 2005 }\end{array} & \begin{array}{c}\text { Scottish } \\ \text { MPs 2005 }\end{array} & \begin{array}{c}\text { MSPs } \\ \mathbf{2 0 0 3}\end{array} \\ \text { Oxbridge } & 16.2 & 6.0 & 20.7 & 2.5 & 0 \\ \text { Other University } & 30.0 & 24.0 & 51.9 & 55.0 & 62.0 \\ \text { Other higher education } & - & - & 18.5 & 20.0 & 28.0 \\ \text { Independent school } & 21.5 & 4.0 & 20.9 & 10.0 & 4.0\end{array}$


5. Educational background of Conservative MPs and MSPs (\%)

$\begin{array}{lccccc} & \begin{array}{c}\text { All Conservative } \\ \text { MPs 1945-70 }\end{array} & \begin{array}{c}\text { Scottish MPs } \\ 1945-70 \\ (1970 \text { only })\end{array} & \begin{array}{c}\text { Scottish } \\ \text { MPs 1992 }\end{array} & \begin{array}{c}\text { Non-Scottish } \\ \text { MPs 2005 }\end{array} & \begin{array}{c}\text { MSPs } \\ \mathbf{2 0 0 3}\end{array} \\ & & & & \\ \text { Oxbridge } & 50.0 & 48.5(65.2) & 27.2 & 44.8 & 5.6 \\ \text { Other University } & 16.0 & 15.3 & 54.5 & 40.2 & 61.1 \\ \begin{array}{l}\text { Other higher } \\ \quad \text { education }\end{array} & - & - & 9.1 & 8.2 & 11.1 \\ \begin{array}{l}\text { Independent school } \\ \text { nd }\end{array} & 77.0 & 63.8(82.6) & 54.5 & 58.0 & 33.3\end{array}$

to Conservatism. ${ }^{21}$ Decline set in from the late 1950 s and the party was pushed back to its rural bases dominated by the traditional upper classes. From the 1970s, however, the party did seem to become more middle class. Comparison with the Scottish Conservative MPs in 1992 (with the usual caveat for the small numbers) suggests that the arrival of the Scottish Parliament in 1999 accelerated this longer-term trend. Two-thirds of Conservative MSPs were educated at state schools, compared with $42 \%$ of all Conservative MPs elected in 2005. Less than $80 \%$ of Conservative MSPs had higher-level qualifications, lower than non-Scottish Conservative MPs $(93 \%)$, and only one $(6 \%)$ was educated at Oxbridge compared to $45 \%$ of non-Scottish Conservative MPs.

The other two major parties in the Scottish Parliament-Scottish National Party (28 MSPs) and Liberal Democrats (17) — continue this professional trend (Table 6). No MSP from these parties has a blue- or routine white-collar background. However, neither party shares Labour's public-sector dominance of its professional category, while business backgrounds are higher in both parties (23\% and $18 \%$ respectively). There are high levels of higher education $(93 \%$ and $83 \%$, respectively) (Table 7). The Liberal Democrat backgrounds are closer to the

6. Backgrounds of SNP and Liberal Democrat politicians (\%)

$\begin{array}{lcccc} & \text { SNP MSPs } & \text { LD MSPs } & \text { LD Scot } & \text { LD non-Scottish } \\ & 2003 & \mathbf{2 0 0 3} & \text { MP 2005 } & \text { MP 2005 } \\ \text { Professional } & 50.0 & 29.4 & 36.4 & 36.7 \\ \text { Business } & 23.1 & 17.6 & 18.2 & 24.5 \\ \text { Blue-collar and white-collar } & 0 & 0 & 0 & 2.0 \\ \text { Other-politics facilitating } & 11.5 & 35.3 & 27.3 & 26.5 \\ \text { Other miscellaneous } & 15.4 & 17.6 & 18.2 & 10.2\end{array}$

7. Educational background SNP and Liberal Democrat politicians (\%)

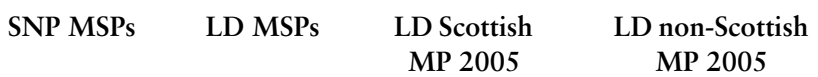

$\begin{array}{lcrrr}\text { Oxbridge } & 0 & 17.6 & 9.1 & 36.7 \\ \text { Other University } & 78.6 & 58.8 & 72.7 & 42.9 \\ \text { Other FE } & 14.3 & 5.9 & 18.2 & 12.2 \\ \text { Independent school } & 10.7 & 35.3 & 27.3 & 44.7\end{array}$


Conservatives, with three Oxbridge graduates (18\%) and 35\% from independent schools, while the SNP is closer to Labour. Further, the largest Liberal Democrat professional category is 'politics-facilitating' (35\%). These figures mirror to some extent the backgrounds of Liberal Democrat MPs in the UK.

The minor parties do little to modify this middle-class professional bias. All seven Green Party MSPs have a university education and three $(43 \%)$ were educated privately. Three $(43 \%)$ are drawn from the public-sector professions, while four $(57 \%)$ worked in and around the voluntary sector. This contrasts with the Scottish Socialist Party MSPs (six), of which three $(50 \%)$ have a further or higher education qualification but none were taught privately. However, all of the SSP's members were drawn from the public sector (two) or politics-facilitating (four) professions; indeed they have tended to be upwardly mobile people of working-class origins taking the same route into politics as previous generations of Labour politicians.

Scottish Labour parliamentary representation used to be marked by a strong municipal element. Between 1945 and 1970, 53\% of Scottish Labour MPs had served in local government, against $43 \%$ of non-Scottish Labour MPs (Table 8). These were often long-serving municipal worthies and even fewer of them than Scottish MPs as a whole made it to ministerial office. ${ }^{22}$ In recent years, as part of the rise of a professional political class, service in local government is increasingly an apprenticeship for Parliament. On the Labour side, $64 \%$ of non-Scottish MPs have municipal experience, while the figure among Scottish MPs has remained rather stable at $54 \%$. Contrary to much casual comment, fewer Labour MSPs (44\%) have a local government background, partly because of an effort by the party not to encourage councillors to take over the new institution.

Until their reconstitution as the Scottish Conservative Party in 1965, the Scottish Tories had rarely contested seats in local government, preferring to back Progressive, Moderate or Independent groupings of notables. The post-war years saw an increase in former councillors on the Conservative side. The party's presence in strength was rather shortlived, as early advances were reversed in the 1980s and 1990s, but there is now a cadre of Conservative former councillors available for higher office. Among Conservative MPs as a whole 30\% are former councillors. This is below the proportion at Holyrood (44\%) although the

8. Former councillors

$\begin{array}{lccccc} & \text { Non-Scottish } & \text { Scottish MPs } & \text { Non-Scottish } & \text { Scottish MPs } & \text { MSPs } \\ & \text { MPs 1945-70 } & \mathbf{1 9 4 5 - 7 0} & \text { MPs 2005 } & \mathbf{2 0 0 5} & \mathbf{2 0 0 3} \\ \text { Labour } & 43.4 & 53.0 & 64.0 & 53.7 & 44.0 \\ \text { Conservative } & 26.2 & 23.6 & 32.0 & \text { na } & 44.4 \\ \text { Liberal Democrat } & \text { na } & \text { na } & 65.3 & 27.3 & 64.7 \\ \text { SNP } & \text { na } & \text { na } & \text { na } & 16.7 & 28.6\end{array}$


small numbers again reduce the significance of this difference. $65 \%$ of Liberal Democrats in Holyrood have local government experience, a figure comparable to that of its non-Scottish MPs, evidence of the way in which the party has built itself up since the 1990s on it municipal base. Only $29 \%$ of the SNP MSPs, however, have come from local government (its six MPs make statistical analysis meaningless).

Another traditional source of recruitment for Labour politicians is the trade union movement. We do not have figures for those having held trade union office in the post-war years, but of non-Scottish Labour MPs elected in 2005, 32\% were former union office holders. Among Scottish Labour MPs the figure was higher at $40 \%$, conforming to the generally more traditional background, but among MSPs it fell to $28 \%$ (Table 9).

Measuring the Scottishness of Scottish politicians is fraught with difficulty, as this is a fluid category, with several available criteria and gradations. ${ }^{23}$ There is no evidence of an ethnic filter or birth criterion. Just three-quarters of all MSPs were born in Scotland and two-thirds were both born and educated there, well under the proportions for the population as a whole. This is consistent with the figures for Scottish MPs. Until the early twentieth century, there had been a substantial number of 'carpet-baggers' in Scotland but these declined rapidly after the First World War and again in the 1950s. ${ }^{24}$ Of the 15 MSPs not born or educated in Scotland, most had quite long residence and indeed eight had names indicating Scottish ancestry. These might be McCrone's 'returning Scots', ${ }^{25}$ with family connections that make it easier to assimilate into Scottish public life.

One of the achievements of the Scottish Parliament has been to increase the number of women in elected office. $40 \%$ of MSPs elected in 2003 were women, just over double the proportion at Westminster (Table 10). This is largely the result of Labour's policy of gender parity in selections for Holyrood, although women accounted for a fifth of Conservative MSPs, also more than twice their proportion at Westminster. Gender equality, however, has been achieved at the cost of social representativeness,

9. Trade union officials among Labour MPs and MPS (\%)

Non-Scottish MPs 2005

Scottish MPs 2005

MSPs 2003

31.5

43.9

28.0

10. Women MPs and MSPs (\%)

Non-Scottish MPs $2005 \quad$ Scottish MPs 2005

MSPs 2003

Labour

28.3

Conservative

8.8

19.5

56.0

Liberal Democrat

16.3

0

22.2

SNP

na

33

11.8

35.7 
since women MSPs are even more professional $(64 \%)$ in their background than their male counterparts $(46 \%)$.

The arrival of new parties in the Scottish Parliament has made it more politically representative, bringing in ideas and political cultures that were for a long time outside the political system. It has not, however, made political leadership more socially representative, but merely reinforced existing trends towards the professional classes.

It is common in devolved or federal systems of government for politicians to move from one level to another. This is not simply a matter of progressing from lower to higher levels in the way politicians graduate from local government to parliament. There is also a flow from the centre or federal level as senior politicians return home to take the leadership of the devolved governments. It is striking that in Scotland this phenomenon appears to be absent. Fifteen MPs made a one-way choice in 1999 to move to the Scottish Parliament, although after 2003 only 10 of them were left. Another eight (six remaining in 2003) MSPs had been MPs in the past, all except one from Scottish constituencies. ${ }^{26}$ Since then no MP or MEP has moved to the Scottish Parliament. Some Conservative MSPs have looked to Westminster, where promotion prospects might be better. One MSP (Conservative David Mundell in 2005) was elected to Westminster for a Scottish constituency and Ben Wallace left the Scottish Parliament to secure a parliamentary seat in England at the same election. The case of Alex Salmond, who resigned from the SNP leadership and stayed at Westminster, then changed his mind to resume both the leadership and the candidacy for his seat at Holyrood (for 2007) is exceptional. The relationship between Westminster and the Scottish Parliament thus shows neither centrifugal nor centripetal tendencies in the form of a career train from periphery to centre or vice versa, such as have been identified in some other federal and devolved systems. ${ }^{27}$ It has its own career structure and apprenticeship paths and provides its own leadership cadre.

This is partly to do with the rules common to Westminster and Holyrood that ministers must be recruited from the ranks of parliamentarians, a rule that does not apply in much of Europe. It is also rooted in the traditional career paths of politicians who need to come up through the backbenches, unlike in other countries. Most of all, it reflects the strategies of the political parties, who have not encouraged the migration of politicians among parliaments, although there has been some movement between Westminster and the European Parliament. Nor have the parties sought to recruit star candidates outwith their own ranks, as happens in Canada as a way to renew the political class. The Liberal Democrats and Conservatives did seek to broaden their base in 1999 by inviting non-members to apply for candidatures (on condition that they joined the party), but none seem to have been elected. Despite the encouragement of the First Minister, the Labour Party refused to waive its rules to admit the candidature of a prominent Asian businessman 
at a Scottish Parliament by-election in 2005. A few closet party supporters had sat in local government as Independents in rural areas where party politics does not operate and one of these, Convenor of Highlands Regional Council, reached high office in the Executive as a Labour MSP. Apart from this mode, which is not new, there was no significant reaching beyond party ranks. Holyrood also resembles Westminster in being a career-based parliament. Unlike in other countries, politicians do not come in and out in the course of their lives since they know that, outside Parliament, they will be forgotten. The influx of novice politicians in 1999, some of whom went straight into Cabinet, thus looks like a one-off effect of the new institution rather than a continuing practice.

\section{The Civil Service}

For many years, commentators have criticised the narrow recruitment base of British senior civil servants, mostly men drawn from upper middleclass families and educated at private schools and Oxbridge. ${ }^{28}$ While the Scottish Office was an integral part of the British civil service and committed to mobility, there was a tendency for civil servants to spend their entire careers there, interrupted sometimes in the case of high flyers by a spell in Whitehall (ideally in Treasury or Cabinet Office) to acquire contacts and know-how. There was an Oxbridge bias, as in 1968 a fifth of administrative class officials in the Scottish Office had degrees from the ancient English universities, but this was much less marked than in the case of Whitehall. ${ }^{29}$ Scottish Office officials tended to be native Scots who stayed mainly in Scotland. Some fears were expressed at the time of devolution that mobility between Edinburgh and London would be restricted and this was a decisive argument in the decision to keep a unified civil service. Yet these fears seem to have been based on an exaggerated idea of the mobility that had existed before, often more of an aspiration and official policy than a reality.

Comparing trends over time is difficult since the grading structure of the civil service has changed considerably. For example, the old administrative class of senior civil servants included new recruits on the fast track as well as higher officials. There is also some difficulty in comparing across Whitehall and the Scottish Executive. The latter has only one Permanent Secretary, making a statistical comparison meaningless. The heads of Scottish departments might be a more meaningful comparison, but they do not enjoy the same rank as heads of Whitehall departments (who are Permanent Secretaries). We therefore present findings for officials at various levels for comparison. There is in fact a fairly clear picture.

There does seem a tendency for the proportion of senior Whitehall civil servants educated privately to fall. Kavanagh and Richards show the number of Permanent Secretaries educated privately fluctuated from $88 \%$ between 1974 and 1979 to $93 \%$ between 1979 and 1990 and to 
$82 \%$ between 1990 and $1995 .{ }^{30}$ Our calculations show that it fell to $68 \%$ among those in office from 1997 to 2004 and in 2004 it was just $62 \%$. Further, if we extend the coverage to grades 1-3 (paybands 2, 3 and PS) then the figure is $42 \% .^{31}$ In Scotland, in $2004,33 \%$ of the senior management (mostly heads of department) and $21 \%$ of heads of group were educated privately. Therefore, if we compare the top civil servants in each arena (Table 11) we find significant Scottish differences, with approximately half the proportion of Scottish civil servants attending private schools (although the effect is less stark with a strict comparison by grade). It is true that England has nearly twice the population of privately-educated pupils as Scotland, but this could not be the sole cause of the difference, since not all of the Scottish senior civil service was educated in Scotland (see below). The significance of private schools in England is not in the number of people they educate (which is very small and even smaller for the elite ones) but in their role in the formation of elites. Scottish private schools do not appear to do this to anything like the same extent.

Scotland has, not surprisingly, always had a smaller proportion of senior civil servants educated at Oxbridge than is found in Whitehall. At $14 \%$, the proportion of Oxbridge graduates among senior Scottish Executive civil servants is about half than that in Whitehall but still significant (Table 12). A third of the Scottish heads of department are Oxbridge graduates compared with over $70 \%$ in Whitehall heads of department (Table 11) or $48 \%$ of Whitehall payband 3 (Table 12). Scottish civil servants tend to have been educated at Scottish universities (64\% of our SCS sample) and there is a smaller proportion than in Whitehall (SCS as a whole) who have not been to university at all, perhaps reflecting Scotland's higher graduate population.

Other measures of 'Scottishness' also suggest that most Scottish Executive civil servants were born $(61 \%)$ and/or schooled $(69 \%)$ in

11. Backgrounds of Permanent Secretaries and senior civil servants in Whitehall and the Scottish Executive ${ }^{32}$

\begin{tabular}{|c|c|c|c|c|c|c|c|c|c|c|}
\hline & \multicolumn{4}{|c|}{$\begin{array}{l}\text { Whitehall Permanent } \\
\text { Secretary heads of } \\
\text { department }\end{array}$} & \multicolumn{6}{|c|}{ Scottish Executive 2004} \\
\hline & \multicolumn{2}{|c|}{2004} & \multicolumn{2}{|c|}{ 1997-2004 } & \multicolumn{2}{|c|}{$\begin{array}{l}\text { Senior } \\
\text { management } \\
\text { group }\end{array}$} & \multicolumn{2}{|c|}{$\begin{array}{l}\text { Heads of } \\
\text { group }\end{array}$} & \multicolumn{2}{|c|}{ Other $\mathrm{SCS}^{33}$} \\
\hline & $\mathbf{n}$ & $\%$ & $\mathrm{n}$ & $\%$ & $\mathbf{n}$ & $\%$ & $\mathbf{n}$ & $\%$ & $\mathbf{n}$ & $\%$ \\
\hline Women & 2 & 13 & 4 & 13 & 1 & 11 & 8 & 20 & 5 & 20 \\
\hline Men & 13 & 87 & 27 & 87 & 8 & 89 & 31 & 80 & 18 & 80 \\
\hline Independent school & 8 & 62 & 19 & 68 & 3 & 33 & 7 & 21 & 8 & 35 \\
\hline State school & 5 & 38 & 9 & 32 & 6 & 67 & 27 & 79 & 15 & 65 \\
\hline Oxbridge & 11 & 73 & 22 & 71 & 3 & 33 & 9 & 26 & 2 & 9 \\
\hline Other University/HE & 4 & 27 & 9 & 29 & 5 & 56 & 24 & 69 & 21 & 91 \\
\hline No University & 0 & 0 & 0 & 0 & 1 & 11 & 2 & 6 & 0 & 0 \\
\hline
\end{tabular}


12. Senior civil service by higher education and payband $2003^{34}$

\begin{tabular}{|c|c|c|c|c|c|c|}
\hline & \multicolumn{5}{|c|}{ Payband } & \multirow[b]{2}{*}{ Total } \\
\hline & 1 & $1 \mathrm{~A}$ & 2 & 3 & PS & \\
\hline \multicolumn{7}{|l|}{ Whitehall departments ${ }^{35}$} \\
\hline No University \% & 28 & 23 & 19 & 19 & 11 & 26 \\
\hline Other University \% & 49 & 53 & 47 & 34 & 41 & 48 \\
\hline Oxbridge $\%$ & 22 & 23 & 34 & 48 & 48 & 26 \\
\hline $\mathrm{n}$ & 2057 & 146 & 541 & 113 & 27 & 2884 \\
\hline \multicolumn{7}{|l|}{ Scottish Executive } \\
\hline No University \% & 8 & 8 & 3 & 11 & 0 & 7 \\
\hline Other University \% & 80 & 87 & 69 & 56 & 100 & 78 \\
\hline Oxbridge $\%$ & 12 & 5 & 29 & 33 & 0 & 14 \\
\hline $\mathrm{n}$ & 118 & 38 & 35 & 9 & 1 & 201 \\
\hline
\end{tabular}

Scotland. This is slightly lower (5 of 9 , or $56 \%$ ) for the senior management group in both measures, while half of the eight university graduates took their degrees in Scotland. Heads of group were slightly more likely to have been born $(65 \%)$, schooled $(74 \%)$ and taught at a university $(65 \%)$ in Scotland.

Mobility still appears to be rather low. Of our SCS sample, 70\% had spent no time in a Whitehall department. While numbers are too small for statistical significance, the figure is higher $(78 \%)$ in the senior management group but slightly lower $(66 \%)$ for heads of group. This last figure reflects the fact that a significant number $(7$, or $20 \%)$ of heads of group had transferred from Whitehall departments, perhaps in reflection of the greater potential for policy-influencing work at a relatively low payband ( 2 or 3 ) within the senior civil service in the Scottish Executive.

While an achievement of the Scottish Parliament has been to increase the number of women in elected office, this has not yet been replicated in the civil service. The number of women appointed to Permanent Secretary level in Whitehall was $0 \%$ between 1974 and 1979, 1.1\% between 1979 and 1990 and 7\% between 1990 and $1995 .{ }^{36}$ By 2004 the figure had increased significantly (albeit from this low base) to $13 \%$ (Table 11). In Scotland the figures are similar if we focus on the most senior levels. One person or $11 \%$ of the senior management group is female, with greater representation in heads of group and other SCS $(20 \%)$. If we examine the SCS as a whole (Table 13), then the picture is mixed. While more women are represented in the lowest paybands ( 1 and 1A, or grades 4 and 5) in Scotland, we see higher representation in the more senior UK posts. Indeed, if we examine payband 3-the equivalent of most of the senior management group-then Whitehall has almost double the proportion of women as does the Scottish Executive.

Devolution has not therefore provoked a sharp change in the civil service in Scotland. Instead the unified British civil service has shared the same trends. This even extends to external recruitment, although 
13. Senior civil service by gender and payband 2003

\begin{tabular}{|c|c|c|c|c|c|c|c|}
\hline $\begin{array}{l}\text { Senior civil } \\
\text { service }\end{array}$ & Gender & 1 & $1 \mathrm{~A}$ & $\begin{array}{c}\text { Payband } \\
2\end{array}$ & 3 & PS & Grand total \\
\hline $\begin{array}{l}\text { Whitehall } \\
\text { departments }^{37}\end{array}$ & $\begin{array}{l}\text { Female* } \\
\text { Male* } \\
\text { Total }\end{array}$ & $\begin{array}{l}681(27) \\
1805(73) \\
2486\end{array}$ & $\begin{array}{l}30(19) \\
124(81) \\
154\end{array}$ & $\begin{array}{l}148(25) \\
444(75) \\
592\end{array}$ & $\begin{array}{l}26(20) \\
107(80) \\
133\end{array}$ & $\begin{array}{l}4(13) \\
28(88) \\
32\end{array}$ & $\begin{array}{l}889(26) \\
2508(74) \\
3397\end{array}$ \\
\hline $\begin{array}{l}\text { Scottish } \\
\text { Executive }\end{array}$ & $\begin{array}{l}\text { Female* }^{*} \\
\text { Male* } \\
\text { Total }\end{array}$ & $\begin{array}{l}42(35) \\
79(65) \\
121\end{array}$ & $\begin{array}{l}9(20) \\
35(80) \\
44\end{array}$ & $\begin{array}{l}5(14) \\
30(86) \\
35\end{array}$ & $\begin{array}{l}1(11) \\
8(89) \\
9\end{array}$ & $\begin{array}{l}0(0) \\
1(100) \\
1\end{array}$ & $\begin{array}{l}57(27) \\
153(73) \\
210\end{array}$ \\
\hline
\end{tabular}

official figures tend to overstate public-private sector mobility and detailed figures are difficult to find. From what we know, external appointments are highest in health departments, reflecting the tradition of recruiting chief medical, nursing and other positions from the NHS. In Whitehall, health accounts for around $20 \%$ of all external appointments and one-third at the payband 3 level. In the Scottish Executive, health accounts for five of ten external appointments. This includes the only appointment within the senior management group, while two of the four appointments at payband 2 level came from the NHS (and two from local government).

\section{Conclusion}

Devolution has caused a shift in political representation in Scotland but, gender aside, it has not widened it. Rather devolution has accelerated the trend towards professional middle-class leadership. From lagging behind the UK in this evolution, Scotland has now overtaken it. This substantiates our second hypothesis, that there has been a change as a result of devolution, but this has not been in a new direction. A distinct Scottish political class has emerged, with its own career trajectory separate from the UK one. This is perhaps not entirely new, since there was a tendency in the post-war years for Scottish MPs to specialise either in Scottish or in UK affairs, but there is now an institutional boundary which forces the choice. Differences in the social class backgrounds of politicians from the main parties have diminished as all have converged on the same professional pattern. Perhaps the most significant difference is the greater tendency for Labour MSPs to be drawn from the public sector but Conservative, SNP and Liberal Democrat MSPs from the private.

Patterns among civil servants have changed less dramatically as they are renewed only slowly and the Scottish Executive inherited its officials from the Scottish Office. They were always drawn less from upper-class backgrounds (as measured by private education) than their Whitehall counterparts and the gap has remained as the upper-class element has 
fallen. Here our hypotheses are not substantiated since devolution has not made a separate impact. The result is a civil service with a class and educational background rather similar to that of the politicians, especially of the ministers in the Executive. Civil servants in the past tended to stay in Scotland during their careers and devolution does not seem to be making a difference here. The Scottish Executive is committed to a similar pattern of civil service reform as is Whitehall, involving more recruitment from outside and open competition for posts. This has produced some results (notably in health) although outsiders have usually come from other parts of the public sector.

We do not have systematic data on the social background of leaders of interest groups and civic associations in Scotland, but our informed impression is that they are led by people of a similar background to the political and administrative elites. ${ }^{38}$ Lindsay Paterson has emphasised the continuing role of middle-class civic Scotland after devolution, contrasting them with other, demotic forces elsewhere in the society. ${ }^{39}$ This is consistent with our findings about elites and the direction in which they are evolving. While bureaucratic and political elites are, as elsewhere in the UK, separate, there is an interpenetration of party politics and civic Scotland as many MSPs are drawn from the ranks of interest groups and voluntary associations, while others come from the publicsector professions involved in similar activities. The presence of private business and of private-sector trade unionists, by contrast, is rather low. It would be an error to read off political attitudes directly from the backgrounds of politicians, but the presence of public-sector professionals is also consistent with the greater consensus in Scotland around traditional models of public service provision and the lesser enthusiasm for the forms of privatisation, quasi-privatisation and competition found in England. It is also consistent with the greater emphasis on consensus and negotiation in public policy-making, in consultation with service providers. ${ }^{40}$

1 The research on which this article is based was funded as part of a study of political and administrative elites based at the Constitution Unit, University College London, forming part of the Leverhulme programme on State and Region in the UK.

2 For a critical discussion, see G. Jordan and L. Stevenson, 'Redemocratizing Scotland' in A. Wright (ed.), Scotland: the Challenge of Devolution, Ashgate, 2001; N. McGarvey, 'New Scottish Politics, New Texts Required', British Journal of Politics and International Relations, October 2001; J. Mitchell, 'The Study of Scottish Politics Post-Devolution', Parliamentary Affairs, October 2001; M. Keating, The Government of Scotland, Edinburgh University Press, 2005.

3 See note 5 below and in particular H. Best and M. Cotta (eds), Parliamentary Representatives in Europe 1848-2000, Oxford University Press, 2000.

4 M. Keating, The Role of the Scottish MP, PhD thesis, Glasgow College of Technology and CNAA, 1975; M. Keating, 'Parliamentary Behaviour as a Test of Scottish Integration in the United Kingdom', Legislative Studies Quarterly, October 1978.

5 This reflects broad West European trends, although the terms 'politics-enabling' or 'politics-facilitating' are often used loosely and the prominence of certain occupations varies in West European countries. See Anthony King, 'The Rise of the Career Politician in Britain - And its Consequences', British Journal of Political Science, July 1981; M. Rush, 'Career Patterns in British Politics', Parliamentary Affairs, October 1994; 
P. Norris and J. Lovenduski, Political Recruitment: Gender, Race and Class in the British Parliament, Cambridge University Press, 1995; P. Norton, 'Roles and Behaviour of British MPs' in T. Saalfeld and W.C. Muller (eds), Members of Parliament in Western Europe, Frank Cass, 1997; T. Saalfeld, ' 'Professionalisation of Parliamentary Roles in Germany' in T. Saalfeld, and W.C. Muller (eds), Members of Parliament in Western Europe, Frank Cass, 1997; H. Best and M. Cotta (eds), Parliamentary Representatives in Europe 1848-2000, Oxford University Press, 2000; M. Shephard, N. McGarvey and M. Cavanagh, 'New Scottish Parliament, New Scottish Parliamentarians?' Journal of Legislative Studies, Summer 2001.

6 Data for MPs between 1945 and 1970 are taken from Keating, op. cit. 'The Role of the Scottish MP' Data on MPs in 2005 and on MSPs were gathered by the authors.

7 It comes as shock to recall that in 1955 the Conservatives not only won an absolute majority of votes and seats in Scotland, but also took seven out the fifteen constituencies in Glasgow. The decline in Conservative fortunes is charted in I.G.C. Hutchison, Scottish Politics in the Twentieth Century, Palgrave, 2001.

8 We thus avoided the trap of simply charting the decline of 'blue-collar' workers, which would have given us some rather commonplace findings.

9 King, op. cit.

10 Saalfeld includes civil servants but this does not seem appropriate for the UK.

11 C. Mellors, The British MP: a socio-economic study of the House of Commons, Saxon House, 1978.

12 That is, including-political worker/ researcher, trade union official, journalist/ media, public relations, quango, interest group/ think tank/ lobbyist, representative of another assembly-but excluding traditional categories such as barrister.

13 King, op. cit.

14 Norton, op. cit.

15 D. Kavanagh and D. Richards, 'Prime Ministers, Ministers and Civil Servants in Britain', Comparative Sociology, January 2003.

16 Shephard et al., op. cit.

17 Lindsay Paterson, Frank Bechhofer and David McCrone, Living in Scotland. Social and Economic Change since 1980, Edinburgh University Press, 2004.

18 According to Paterson et al., op. cit., from those born between 1937 and 1946 to those born between 1967 and 1976 the percentage of the 'service class' (Goldthorpe categories 1 and 11) increased from $29.5 \%$ to $38 \%$. This is not exactly equivalent to our category, but it suggests that the professionalisation of Scottish politicians is faster than that of the population as a whole.

19 Again taking the roughly equivalent Goldthorpe categories from Paterson et al., op. cit., it would be around $40 \%$.

20 Higher educational qualifications are those at Higher National Diploma and above. In Scotland, a higher proportion of higher education is delivered in further education colleges than in England. This no doubt accounts for the higher 'other higher education' figure among Scottish politicians.

21 Hutchison, op. cit.

22 M. Keating, 'Labour in Scotland, 1951-65' in I. Donnachie, C. Harvie and I.S. Wood (eds), Forward! Labour Politics in Scotland, 1888-1988, Edinburgh University Press, 1988.

23 D. McCrone, 'Who are We? Understanding Scottish Identity' in C. Domenico, A. Law, J. Skinner and M. Smith (eds), Boundaries and Identities. Nation, Politics and Culture in Scotland, University of Abertay Press, 2001.

24 Keating, op. cit.; J. Kellas, The Scottish Political System, Cambridge University Press, 1973.

25 McCrone, op. cit.

26 P. Lynch, Scottish Government and Politics, Edinburgh University Press, 2001.

27 K. Stolz, 'Moving up, moving down: Political careers across territorial levels', European Journal of Political Research, March 2003.

28 R. Kelsall, Higher Civil Servants in Britain, Routledge, 1955; K. Theakston and G. Fry, 'Britain's Administrative Elite: Permanent Secretaries 1900-1986', Public Administration, Summer 1989; P. Barberis, Elite of the Elite. Permanent Secretaries in the British Higher Civil Service, Dartmouth, 1996.

29 Kellas, op. cit.

30 Kavanagh and Richards, op. cit.

31 From a 1994 survey-C. Dargie and R. Locke, 'The British Senior Civil Service' in E. Page and V. Wright (eds), Bureaucratic Elites in Western European States, Oxford University Press, 1999.

32 Source: Who's Who (UK) and correspondence. In post rather than newly appointed. NAW and NIO departments excluded. Some figures are not available. The table uses valid $\%$.

33 In head of group-equivalent positions. There are approximately 210 SCS in Scotland, while our sample of relatively senior SCS amounts to 71 .

34 Source: SCS Database, Personnel Statistics, Cabinet Office (in correspondence). The table excludes the category of 'Not Known' ( $\mathrm{n}=513$ ) from the figures. FCO data is not available. Permanent Secretaries from agencies and those who do not head departments are included. 
$3544(63 \%)$ of the Treasury's 70 SCS graduated from Oxford or Cambridge.

36 Kavanagh and Richards, op. cit.

37 The MOD has $17(6 \%)$ female SCS out of 262 . Twelve of these are in payband 1 and five in payband 2 . Similarly, with GCHQ there are $3(9 \%)$ of 32 . All three are in payband 1.

38 As part of our research on interest groups and policy communities in Scotland we carried out around 100 interviews between 2000 and 2004 .

39 L. Paterson, 'Civic Democracy' in G. Hassan and C. Warhurst (eds), Anatomy of the New Scotland, Mainstream, 2002.

40 M. Keating, The Government of Scotland. Public Policy Making after Devolution, Edinburgh: Edinburgh University Press, 2005. 